\title{
Upland Rice Performance through N, P, K Fertilizers and Weed (Mimosa invisa L.) Extract Applications.
}

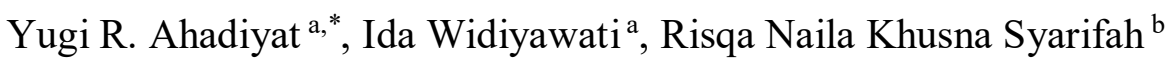 \\ ${ }^{a}$ Laboratory of Agroecology, Department of Agrotechnology, Faculty of Agriculture, Universitas Jenderal Soedirman, Purwokerto 53123, \\ Central Java, Indonesia \\ ${ }^{b}$ Laboratory of Agronomy, Department of Agrotechnology, Faculty of Agriculture, Universitas Jenderal Soedirman, Purwokerto 53123, \\ Central Java, Indonesia \\ Corresponding author: ${ }^{*}$ ahadiyat.yugi@unsoed.ac.id
}

\begin{abstract}
Weed may be defined as plants or vegetation that interferes with the farming systems. However, using weeds as a natural resource to support crop production is still unexplored. Mimosa invisa is one of the main weeds of dry land with a wide distribution level. Therefore, the utility of this weed is expected to increase the efficiency of using synthetic fertilizers to gain optimal production. The objective of this study was to determine the effect of $\mathrm{N}, \mathrm{P}, \mathrm{K}$ fertilizers, and weed (Mimosa invisa L.) extract on plant growth and physiological characters and yield of upland rice. A split-plot design with the main plot of $\mathrm{N}, \mathrm{P}, \mathrm{K}$ fertilizer dose viz. $50 \% \mathrm{~N}, \mathrm{P}, \mathrm{K}$ and $100 \% \mathrm{~N}, \mathrm{P}, \mathrm{K}$ and subplot of weed extract viz. concentration of $0 \% ; 1.25 \% ; 1.67 \% ; 2.5 \%$ and $5 \%$ were tested. Each treatment was replicated three times. Observed variables were growth characters, i.e., plant height, leaf area, shoot dry weight, root dry weight, physiological characters, i.e., proline, chlorophyll a, chlorophyll $b, \mathbf{N}$ and $\mathrm{P}$ contents in rice shoot, and yield components, i.e., the number of productive tillers, weight of grain hill $^{-1}$, number of grains hill ${ }^{-1}$, the weight of 1000 seeds, percentage of filled grains, the weight of grain ha $\mathrm{h}^{-1}$. The results showed that $5 \%$ weed extract improved plant height, leaf area, shoot $\mathrm{P}$ content, grain weight ha-1, and increased efficiency in $\mathrm{N}, \mathrm{P}, \mathrm{K}$ fertilizer application, and high $\mathrm{N}$ shoot content.
\end{abstract}

Keywords - Extract of Mimosa invisa L.; plant growth and physiological characters; synthetic fertilizers; upland rice; yield.

\section{INTRODUCTION}

In most countries in Asia and Africa, rice plays a vital role in the economy and is a staple food, including Indonesians. Consumption of rice has reached $150 \mathrm{~kg}$ per capita in the Indonesian population per year in 2017 , so it means that the adequacy of rice stocks as the main carbohydrate source is still identical for food security [1]. Therefore, the main agendas must be arranged to fulfill rice needs through encourage production systems.

The availability of dryland in the world is quite extensive, with great potential about $40 \%$ in developing countries, and has not been utilized properly [2]. Currently, Indonesian rice production has always and focused on irrigated rice farming. Meanwhile, the contribution of upland rice from dryland areas that its available spread in many islands in Indonesia has not been utilized optimally yet [3]. Therefore, dryland in Indonesia has potency due to large areas to be developed as field rice with upland rice harvested area reached about 1.2 million ha but have not become an alternative solution to establishment national rice production [1].

Improving technology, rice varieties, and cultivation techniques with the proper land management system are needed to maintain the quality and quantity of upland rice. Thus, the benefit of upland rice is adaptively grown in various agroecosystems and soil types [1]. Upland rice began to be widely developed in various regions of the world because of its cultivation which saves more water and can support the irrigated rice production, especially in Indonesia.

To improve rice production in dryland areas, the application of fertilizer as plant nutrition is one thing that must be done. However, the excessive use of synthetic fertilizers and the ability of the soil to provide nutrients lead to decreases in production [4] and the survival of soil organisms [5]. Based on social potential, farmers in some dryland areas in Indonesia are interested in developing organic farming concepts [1].

It has been proven that agricultural systems based on high input energy such as fertilizers and synthetic pesticides can damage the soil, reduce soil productivity, and affect crop 
production [6]. Organic agriculture management with a holistic agricultural system supports the sustainability and improvement of the health of the soil, plants, animals, earth, and humans as a unit because all these components are interconnected and inseparable [6].

Organic agriculture is an agricultural system oriented to using local natural materials without or reducing the application of fertilizers and synthetic pesticides. The continuous use of synthetic fertilizers in cropping systems in dryland areas harms soil productivity and the environment. One of the indicators of a decrease in soil quality is low soil C content [7]. The organic farming system approach will help improve soil quality by which will support crop production. Therefore, organic matter and environmentally friendly additives can be used as an alternative to synthetic fertilizers in maintaining environmental balance.

Organic farming is focused on increasing yield, being environmentally friendly, and being sustainable in agriculture production. Indonesia has considerable potential and opportunities to develop organic agriculture due to abundant natural resources. Natural resources have the potential to increase crop growth and yield and reduce the use of synthetic fertilizers. One of the natural resources, such as weeds can be used, which are considered disadvantaged plants in the cultivation system but have other functions that can be utilized.

Environmental conditions and physiological processes in plants strongly impact the production of primary and secondary metabolites [8]. Under stress condition, secondary metabolite production increases to against abiotic and biotic stresses and directly reduce the quality and quantity in mostly crops [9], but it has been found in medicinal and aromatic plant vice versa [8]. This indicated that secondary metabolites positively respond in such plants more than protection and maintaining plants to survive in stressful environmental conditions.

Weed as a biotic stress problem is a major constraint in crop production and may substantially reduce many yields when uncontrolled properly, even depending on the crop, ecological and climatic conditions. But, weeds have potential benefits due to some secondary metabolites content such as alkaloids, tannins, saponins, phenolics, terpenoids, steroids, and essential oils [10]. The study had been carried out through the application of weed extract, i.e., Chromolaema odorata, Ageratum conyzoides, Cyperus kyllinga, Cyperus rotundus [10], and Artemisia arborescens, Rhus coriaria, Lantana camara, Thymus vulgaris, Euphorbia characias [11] on the performance of crops.

Mimosa invisa L. is a widely distributed plant and has been known throughout the world. This legume has been widely grown in most parts of Asia, Africa, and several Pacific islands such as Australia and Papua New Guinea, which have developed dominantly in vegetation [12]. But it has not been explored yet as biomass extract and the application on crops, especially on rice performance. Some chemical contents are secondary metabolites in this weed, i.e., mimosin, pipekolinic acid, tannins, alkaloids, saponins, triterpenoids, sterols, polyphenols, etc. flavonoids, proteins, and steroids [13]. Secondary metabolites are also involved in plant reproduction and can be a supplier of nitrogen which is beneficial for plant growth due to some secondary plant metabolites are nitrogenous organic molecules [9]. Therefore, this weed is the potential to develop as organic biomass in agriculture production.

Upland rice cultivation by combining the use of biomassderived from plant extracts such as weeds can increase the carrying capacity of agricultural land, efficient use of fertilizers, and increase crop production. However, the effect of weed extract (Mimosa invisa L.) with different doses of N, $\mathrm{P}, \mathrm{K}$ fertilizers has not been yet known on upland rice performance. The objective of this study was to determine the effect of N, P, K fertilizer dose, and weed extract concentration on plant growth and physiological characters and yield of upland rice.

\section{MATERIALS AND METHODS}

\section{A. Site Location, Climatic and Soil Conditions}

The study was conducted in the dryland area in Kalimandi Village, Purwareja District, Banjarnegara Regency, Central Java Indonesia, with $110 \mathrm{~m}$ above sea level during the dry season from April to July 2017. Rainfall intensity, temperature, and relative humidity were observed regularly during the study, as shown in Figure 1. During the study, rainfall intensity was very low the study about less than 80 $\mathrm{mm}$ per month in April and almost $40 \mathrm{~mm}$ and $60 \mathrm{~mm}$ per month in May and June, respectively. In July is shown the lowest rainfall intensity of about $20 \mathrm{~mm}$ per month. Temperature and relative humidity was plane around $25{ }^{\circ} \mathrm{C}-$ $28{ }^{\circ} \mathrm{C}$ and $76 \%-80 \%$, respectively. Chemical soil character was slightly acid with low in $\mathrm{N}$ total, available $\mathrm{P}$, and cation exchange capacity but high in extractable $\mathrm{K}$ and organic carbon, as shown in Table 1. Soil conditions were high in soil carbon content but low in the availability of major nutrients with low cation exchange capacity categorized as less fertile soils.

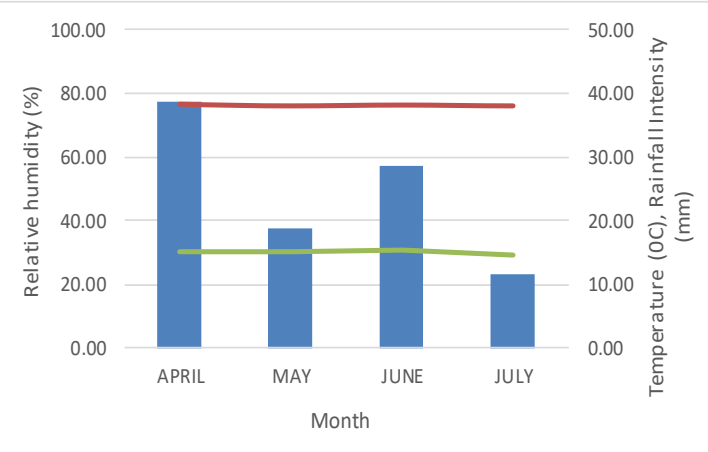

Rainfall Intensity (mm) Relative Humidity (\%) Temperature (OC)

Fig. 1 Rainfall intensity, temperature, and relative humidity during the study.

\section{B. Experimental Design and Treatments}

Upland rice variety of Inpago Unsoed 1 with a seeding rate of $15 \mathrm{~kg} \mathrm{ha}^{-1}$ was sown by direct seeded with the help of hand drill in the fine prepared field. Fertilizers of $\mathrm{N}$ [urea], $\mathrm{P}_{2} \mathrm{O}_{5}$ [Super Phosphate 36], and $\mathrm{K}_{2} \mathrm{O}$ [Potassium Chloride] were applied i.e., $100 \mathrm{~kg} \mathrm{ha}^{-1}, 100 \mathrm{~kg} \mathrm{ha}^{-1}$, and $50 \mathrm{~kg} \mathrm{ha}^{-1}$, respectively as recommended dose based on soil chemical analysis as the rate giving a maximum yield as presented in Table 1. 
TABLE I

ChEMICAL Characteristics OF SoIl Before Sowing

\begin{tabular}{|c|c|}
\hline Parameter & Value \\
\hline $\mathrm{pH}-\mathrm{H}_{2} \mathrm{O}[\mathrm{pH} 1: 5]^{1}$ & 5.84 \\
\hline C-organic $[\%]^{2}$ & 5.17 \\
\hline N-Total $[\%]^{3}$ & 0.17 \\
\hline Available $\mathrm{P}[\mathrm{ppm}]^{4}$ & 5.36 \\
\hline Extractable K $[\mathrm{ppm}]^{5}$ & 145.41 \\
\hline Cation Exchange Capacity $\left[\mathrm{cmol}^{[+]} \mathrm{kg}^{-1}\right]^{6}$ & 15.42 \\
\hline
\end{tabular}

A split-plot design in a randomized complete block with the main plot of N, P, K, namely $50 \% \mathrm{~N}, \mathrm{P}, \mathrm{K}$, and $100 \% \mathrm{~N}$, $\mathrm{P}, \mathrm{K}$ recommended dose and subplot of weed [Mimosa invisa L.] extract concentration as follows $0 \% ; 1 \%, 1.25 \% ; 1.67 \%$; $2.5 \%$ and $5 \%$ with three replications were tested. Based on treatment, whole potash, phosphorus, and one-third of nitrogen were applied at sowing. The remaining nitrogen was applied at the tillering and panicle initiation stages. Weed [whole plant] extract was applied with a concentration based on treatment. Application of weed extract was sprayed on the whole plant every week up to 2 weeks before harvest time.

The chemical content of weed was analyzed, as shown in Table 2. The arrangement of each plot size was $2.0 \mathrm{~m} \times 4.0 \mathrm{~m}$ with distances $0.5 \mathrm{~m}$ between plots and $1.0 \mathrm{~m}$ between blocks. Weeds were controlled through manual labor by hand weeding when needed. There was no application of synthetic pesticides to control pests and diseases to maintain the organic farming approach. Sprinkler irrigation was applied for water requirement per two days with a volume of $1 \mathrm{~L} \mathrm{~m}^{-2}$ on average until two weeks before harvest time, only to maintain upland rice condition during the slightly extreme dry season.

TABLE II

CHEMICAL ANALYSIS OF WEED [MIMOSA INVISA L.] EXTRACT

\begin{tabular}{|c|c|}
\hline Parameter & Value \\
\hline Total Phenol [mg GAE g-1] & 99.40 \\
\hline Total Flavanoid [mg QE g $\mathrm{g}^{-1}$ ] & 3.20 \\
\hline Total Alkaloid [mg CE g-1] & 0.40 \\
\hline
\end{tabular}

\section{Sample Collection, Data Analysis, and Flow Chart study}

Observed variables were growth characters, i.e., plant height, leaf area, dry weight of shoot and root, and physiological characters, i.e., shoot proline content [14], leaf chlorophyll content [15], and shoot content of N and P [16]. These variables were taken from 5 plants sample within the end of the vegetative stage. Yield components were the number of productive tillers, number and weight of seeds hill ${ }^{-}$ ${ }^{1}$, the weight of 1000 seeds, percentage of filled seeds, and seed weight ha ${ }^{-1}$.

Data were analyzed using $\mathrm{F}$ test at $p \leq 0.05$ using IRRI [17] to determine the significance level of each treatment factor; if there are significant differences. It was continued to analyze by Duncan's Multiple Range Test at $p \leq 0.05$. The flow chart is shown in Figure 2 to give brief information of the step of this study, based on an exploration of the potency of Mimosa invisa to improve crop performance and reduce the synthetic N-P-K fertilizers.

\section{Exploration natural resource}

- Weed of Mimosa invisa is a natural resource

- Mimosa invisa was extracted

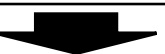

\section{Application in upland rice farming}

- Different concentration of Mimosa invisa extract

- Different dose of N-P-K fertilizers
Upland rice observation
- Plant growth characters
- Plant physiological characters
- Yield and yield components

\section{Analysis due to Mimosa invisa application on \\ - Improvement of upland rice performance \\ - Reduction in N-P-K fertilizers application}

Fig. 2 Flow chart the steps of this study.

\section{RESULTS AND DISCUSSION}

\section{A. Plant Growth Characters}

There was no statistical difference due to N, P, K fertilizer application of $50 \%$ and $100 \%$ recommended dose in plant height about $76.81 \mathrm{~cm}$ and $78.09 \mathrm{~cm}$, and leaf area about $38.18 \mathrm{~cm}^{2}$ and $42.70 \mathrm{~cm}^{2}$, respectively. Plant height increased significantly due to the application of weed extract in a concentration of $1.67 \%, 2.5 \%$, and $5 \%$, about $79 \mathrm{~cm}$ to $81 \mathrm{~cm}$, as shown in Figure 3.

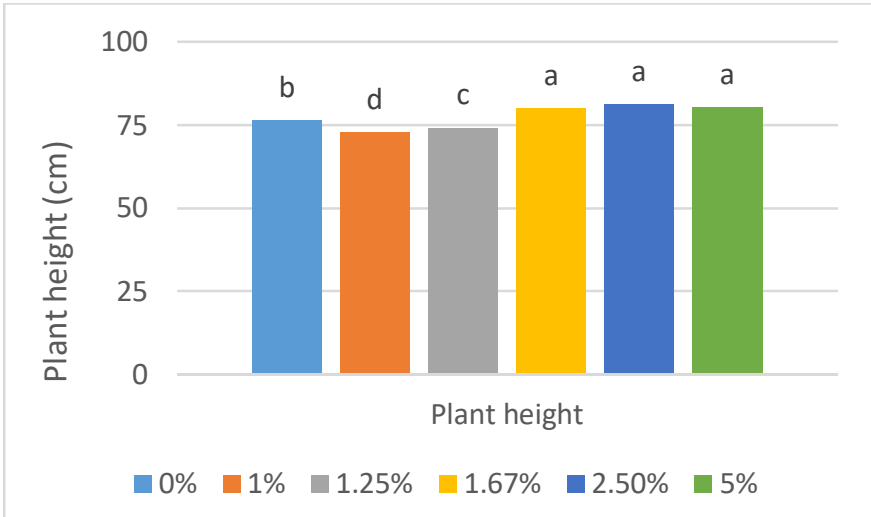

Fig. 3 Effect of weed extract application in different concentration on plant height of upland rice.

The leaf area increased significantly following the addition of weed extract concentration, with an increase with no application of weed extract from $39.08 \mathrm{~cm}^{2}$ to approximately $43.13 \mathrm{~cm}^{2}$ for $5 \%$ weed extract concentration as maximum rate as shown in Figure 4. Even increasing concentration of weed extract improved significantly but there was no interaction between both applications of N, P, K fertilizer, and weed extract on plant height and leaf area. 


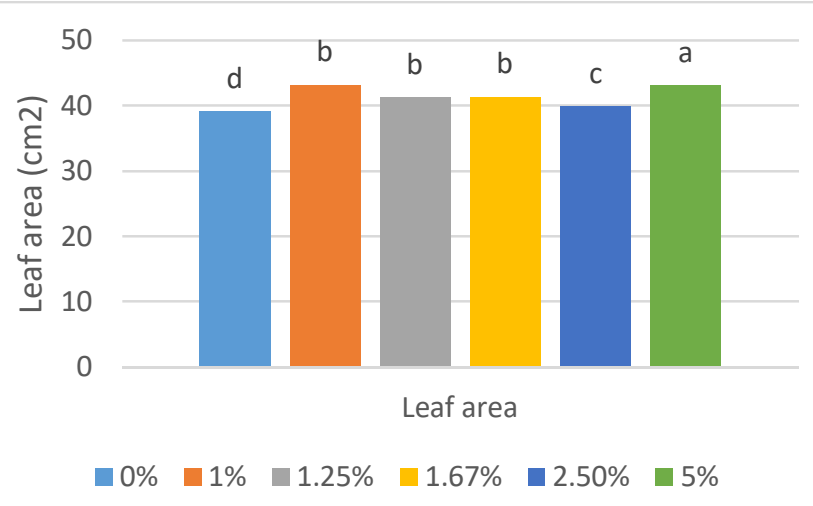

Fig. 4 Effect of weed extract application in different concentrations on leaf area of upland rice.

Application of different doses of N, P, K fertilizer did not affect the shoot and dry root weights, with the results in a range of $25 \mathrm{~g}-28 \mathrm{~g}$ and $4 \mathrm{~g}-5 \mathrm{~g}$, respectively. However, shoot and dry root weights tended to increase with the highest shoot and dry root weights of $31.13 \mathrm{~g}$ and $6.03 \mathrm{~g}$, respectively, recorded at the level of weed extract concentration of $5 \%$.

There was an interaction between N, P, K fertilizers, and weed extract applications on the shoot and dry root weights, as shown in Figures 5 and 6 . These results indicated a strong relationship between both treatments on the shoot and dry root weights. An increase in N, P, K fertilizer dose and weed extract concentration significantly improved shoot and dry root weights, as shown in Figures 5 and 6.

Application of weed extract in the concentration of $1.25-$ $5 \%$ with $100 \%$ recommended dose of $\mathrm{N}, \mathrm{P}, \mathrm{K}$ resulted in relatively higher shoot and dry root weights. However, the application of $100 \% \mathrm{~N}, \mathrm{P}, \mathrm{K}$ recommendation dose and weed extract in a concentration of $5 \%$ resulted in higher shoot and root dry weights compared to other treatments.

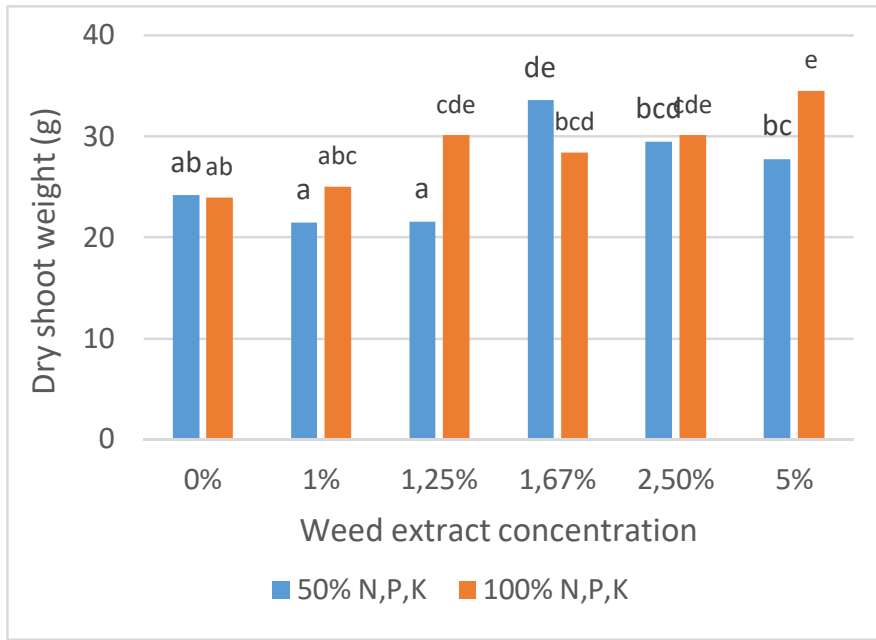

Fig. 5 Effect of N, P, K fertilizers and weed extract applications on upland rice dry shoot weight.

\section{B. Physiological Characters}

Table 3 shows that different dose of N, P, K fertilizers gave no statistical difference effect on leaf contents of proline [10 $\mu \mathrm{mol} \mathrm{g} \mathrm{g}^{-1}-13 \mu \mathrm{mol} \mathrm{g}^{-1}$, chlorophyll a [3 $\left.\mathrm{mg} \mathrm{g}^{-1}-4 \mathrm{mg} \mathrm{g}^{-1}\right]$, chlorophyll b $\left[1 \mathrm{mg} \mathrm{g}^{-1}-1.5 \mathrm{mg} \mathrm{g}^{-1}\right]$, and, $\mathrm{N}[27 \%-30 \%$ ] and $\mathrm{P}[2 \%-3 \%]$ shoot contents of upland rice. Leaf contents of proline, Chlorophyll a, Chlorophyll b varied in range of 8 $\mu \mathrm{mol} \mathrm{g}{ }^{-1}-17 \mu \mathrm{mol} \mathrm{g}^{-1}, 3 \mathrm{mg} \mathrm{g}^{-1}-4 \mathrm{mg} \mathrm{g}^{-1}$ and $1 \mathrm{mg} \mathrm{g}^{-1}-1.6$ $\mathrm{mg} \mathrm{g}^{-1}$, respectively, with no significant differences. This result indicated that the application of $\mathrm{N}, \mathrm{P}, \mathrm{K}$ and weed extract in different rate could not affect in accumulation of proline, chlorophyll a and chlorophyll b.

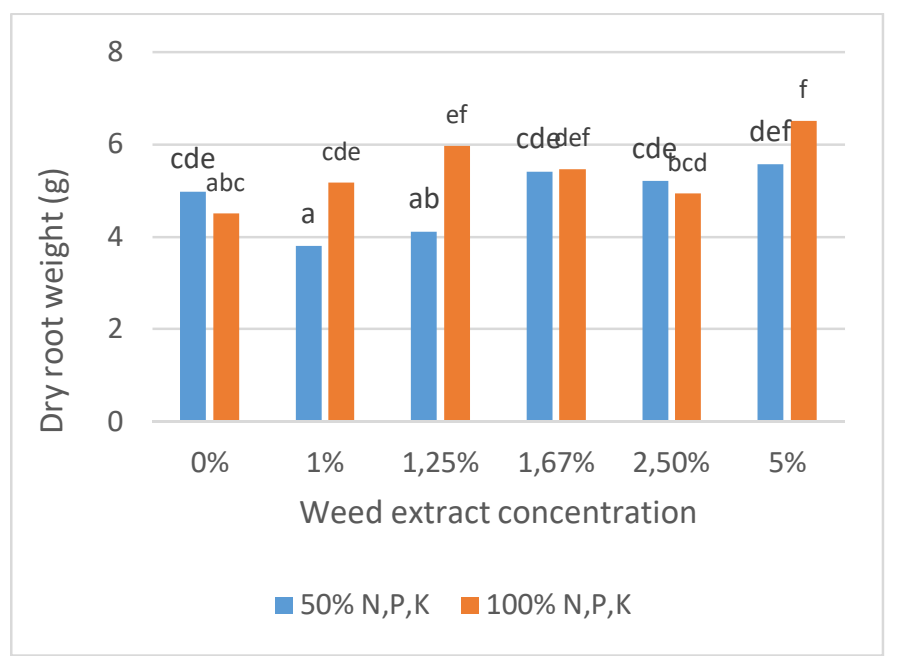

Fig. 6 Effect of N, P, K fertilizers and weed extract applications on dry root weight of upland rice.

TABLE III

APPLICATION OF N,P,K FERTILIZERS AND WEED EXTRACT ON PHYSIOLOGICAL CHARACTERS OF UPLAND Rice

\begin{tabular}{cccc}
\hline Treatments & $\begin{array}{c}\text { Proline content } \\
{\left[\boldsymbol{\mu} \mathbf{m o l ~ g}^{-\mathbf{1}} \mathbf{F W}\right]}\end{array}$ & $\begin{array}{c}\text { Chlor. a } \\
{\left[\mathbf{m g ~ g}^{-1} \mathbf{F W}\right]}\end{array}$ & $\begin{array}{c}\text { Chlor. b } \\
{\left[\mathbf{m g ~ g}^{-1} \mathbf{F W}\right]}\end{array}$ \\
\hline A. N, P, K ${ }^{1}$ & & & \\
$50 \%$ & 10.59 & 3.69 & 1.41 \\
$100 \%$ & 13.32 & 4.10 & 1.48 \\
\hline F-test & $\mathrm{ns}$ & $\mathrm{ns}$ & $\mathrm{Ns}$ \\
\hline B. Weed extract ${ }^{2}$ & & & \\
$0 \%$ & 8.54 & 4.06 & 1.59 \\
$1 \%$ & 9.22 & 4.28 & 1.61 \\
$1,25 \%$ & 17.90 & 3.94 & 1.33 \\
$1,67 \%$ & 13.33 & 3.83 & 1.33 \\
$2,5 \%$ & 12.90 & 3.57 & 1.47 \\
$5 \%$ & 9.88 & 3.74 & 1.32 \\
\hline F-test & $\mathrm{ns}$ & $\mathrm{ns}$ & $\mathrm{ns}$ \\
\hline \%CV & 24.96 & 17.19 & 14.55 \\
\hline FW & &
\end{tabular}

$\mathrm{FW}=$ fresh weight; DW $=$ dry weight, Chlor.=chlorophyll content. Values in the same column with different lowercase superscript letters differ significantly at $p \leq 0.05$, according to Duncan's Multiple Range Test. ns $=$ non-significant; ${ }^{* *}$ significantly different at 0.01 probability levels. $\mathrm{CV}=$ Coefficient of variation. 1. \% of Recommendation dose viz. $50 \%\left[\mathrm{~N}, \mathrm{P}_{2} \mathrm{O}_{5}\right.$ and $\mathrm{K}_{2} \mathrm{O}$ were $0 \mathrm{~kg} \mathrm{ha}^{-1}, 50 \mathrm{~kg} \mathrm{ha}^{-1}$ and $25 \mathrm{~kg} \mathrm{ha}^{-1}$, respectively] and $100 \%$ [N, $\mathrm{P}_{2} \mathrm{O}_{5}$ and $\mathrm{K}_{2} \mathrm{O}$ were $100 \mathrm{~kg} \mathrm{ha}^{-1}, 100 \mathrm{~kg} \mathrm{ha}^{-1}$ and $50 \mathrm{~kg} \mathrm{ha}^{-1}$, respectively]; 2. \% of concentration.

However, significant differences in $\mathrm{N}$ and $\mathrm{P}$ shoot contents varied from $21 \%-33 \%$ and $2 \%-3 \%$, respectively, caused by weed extract application, as shown in Figures 7 and 8. A high $\mathrm{N}$ and $\mathrm{P}$ shoot content was found in the treatment of $2.5 \%$ weed extract concentration about $33.84 \%$ and $3.62 \%$. Increasing the application of weed extract of $1.25 \%$ and above and the application of $100 \% \mathrm{~N}, \mathrm{P}, \mathrm{K}$ fertilizers improve $\mathrm{N}$ shoot content, as shown in Figure 7. Meanwhile, improving $\mathrm{P}$ shoot content happened with the application of weed extract in a concentration of $1.67 \%$ and above, as shown in Figure 8.

There was an interaction between N, P, K fertilizers, and weed extract on $\mathrm{N}$ shoot content. An increase in the dose of both applications significantly improved $\mathrm{N}$ shoot content as 
indicated in a strong relationship as shown in Figure 7. But, different doses of N, P, K fertilizers have no effect on P shoot content with or without the application of weed extract. There was a positive response due to the application of weed extract to improve $\mathrm{P}$ shoot content.

Application of $\mathrm{N}, \mathrm{P}, \mathrm{K}$ fertilizers in the different recommended doses of $50 \%$ and $100 \%$ and weed extract in the concentration of $1.25-5 \%$ improved $\mathrm{N}$ shoot content. That indicated the combination treatments of low dose N, P, $\mathrm{K}$ fertilizers with weed extract had the potency to increase the accumulation of $\mathrm{N}$ in shoot rice plants and reduce the application of synthetic fertilizer.

There had a different response of N, P, K fertilizers, and weed extract applications on $\mathrm{P}$ shoot content. A high dose of $\mathrm{N}, \mathrm{P}, \mathrm{K}$ fertilizers could increase the accumulation of $\mathrm{P}$ in the shoot rice plant. Nevertheless, increasing the concentration of weed extract improved the P shoot content. Therefore, the application of weed extract had an advantage in improving $\mathrm{P}$ content in rice plants in a low dose of $\mathrm{N}, \mathrm{P}, \mathrm{K}$ fertilizers.

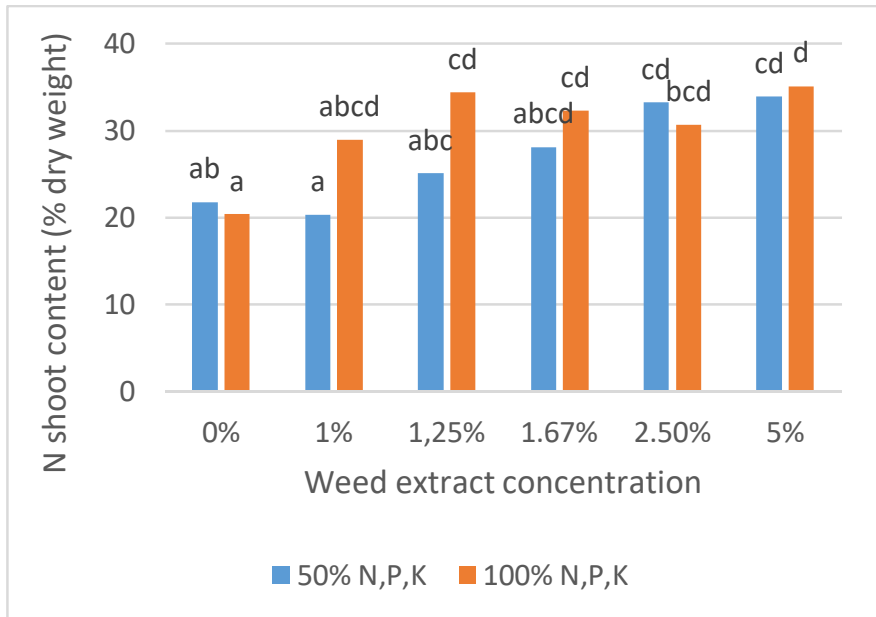

Fig. 7 Effect of N, P, K fertilizers and weed extract applications on $\mathrm{N}$ shoot content of upland rice.

\section{Yield and Yield Components}

Yield components were significantly affected due to N, P, $\mathrm{K}$ fertilizers, and weed extract application. The application of $100 \%$ recommended dose of N, P, K fertilizers significantly improved the number of productive tillers, weight of grain hill $^{-1}$, number of grain hill ${ }^{-1}$, and grain weight ha ${ }^{-1}$ but did not affect the weight of 1000 seeds and number of productive tillers.

The highest result of a number of productive tillers, weight of grain hill-1 ${ }^{-1}$ number of grain hill-1, and grain weight ha $^{-1}$ obtained in application of $100 \%$ recommended dose of N, P, K fertilizers viz. 20.40, 30.03, 1670.21, and $4.80 \mathrm{t} \mathrm{ha}^{-1}$, respectively. But the weight of 1000 seeds $[23 \mathrm{~g}]$ and the percentage of filled grains [61\%] were not affected by the different doses of N, P, K fertilizers, as shown in Table 4. The weight of grain hill ${ }^{-1}$, number of grain hill ${ }^{-1}$, weight of 1000 seeds, number of productive tillers, and grain weight ha $^{-1}$ tended to increase in the weed extract application of $2.5 \%$ and $5 \%$ with the highest results about $34,1790,24 \mathrm{~g}, 64$ and $5 \mathrm{t}$ $\mathrm{ha}^{-1}$, respectively as shown in Table 4.

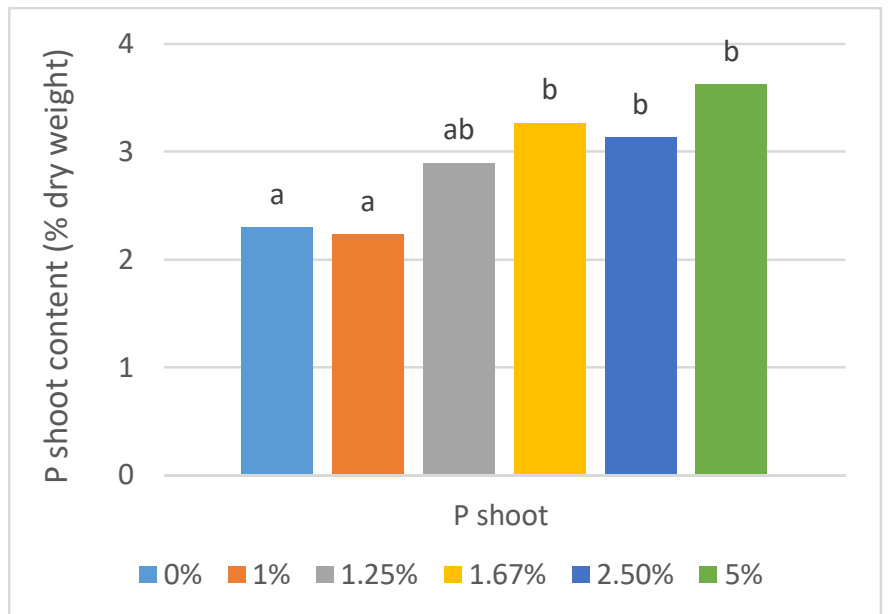

Fig. 8 Effect of weed extract application in different concentrations on $\mathrm{P}$ shoot content of upland rice.

There were significant differences in yield components due to the application of high doses of $\mathrm{N}, \mathrm{P}, \mathrm{K}$ fertilizers, and weed extract concentration, but there was no interaction.

TABLE IV

APPLICATIONS OF N, P, K FERTILIZERS AND WEED EXTRACT ON YIELD AND YIELD COMPONENTS OF UPLAND RICE

\begin{tabular}{ccccccc}
\hline Treatment & NP & WGH & NGH & W1000 & PFG & GW \\
\hline A. N, P, K & & & & & & \\
$50 \%$ & $18.93^{\mathrm{b}}$ & $26.76^{\mathrm{b}}$ & $1467.32^{\mathrm{b}}$ & 23.62 & 61.65 & $4.28^{\mathrm{b}}$ \\
$100 \%$ & $20.40^{\mathrm{a}}$ & $30.03^{\mathrm{a}}$ & $1670.21^{\mathrm{a}}$ & 23.08 & 60.75 & $4.80^{\mathrm{a}}$ \\
\hline$F$-test & ${ }^{*}$ & ${ }^{* *}$ & $* *$ & $\mathrm{~ns}$ & $\mathrm{~ns}$ & $*$ \\
\hline
\end{tabular}

\begin{tabular}{ccccccc}
\hline $\begin{array}{l}\text { B.Weed } \\
\text { extract }\end{array}$ & & & & & & \\
$0 \%$ & 18.97 & $23.52^{\mathrm{c}}$ & $1357.43^{\mathrm{c}}$ & $22.88^{\mathrm{d}}$ & $57.94^{\mathrm{c}}$ & $3.76^{\mathrm{c}}$ \\
$1 \%$ & 19.20 & $23.89^{\mathrm{c}}$ & $1389.99^{\mathrm{c}}$ & $22.61^{\mathrm{d}}$ & $59.73^{\mathrm{b}}$ & $3.82^{\mathrm{c}}$ \\
$1,25 \%$ & 19.23 & $23.44^{\mathrm{c}}$ & $1424.68^{\mathrm{c}}$ & $22.11^{\mathrm{e}}$ & $55.38^{\mathrm{d}}$ & $3.75^{\mathrm{c}}$ \\
$1,67 \%$ & 20.00 & $31.63^{\mathrm{b}}$ & $1684.33^{\mathrm{b}}$ & $23.60^{\mathrm{c}}$ & $64.96^{\mathrm{a}}$ & $5.06^{\mathrm{b}}$ \\
$2,5 \%$ & 19.87 & $34.34^{\mathrm{a}}$ & $1765.98^{\mathrm{ab}}$ & $24.66^{\mathrm{a}}$ & $64.95^{\mathrm{a}}$ & $5.49^{\mathrm{a}}$ \\
$5 \%$ & 20.73 & $33.55^{\mathrm{a}}$ & $1790.15^{\mathrm{a}}$ & $24.24^{\mathrm{b}}$ & $64.26^{\mathrm{a}}$ & $5.37^{\mathrm{a}}$ \\
\hline F-test & ns & $*$ & $*$ & $* *$ & $* *$ & $*$ \\
\hline$\% \mathrm{CV}$ & 14.49 & 16.02 & 15.52 & 4.18 & 3.94 & 16.08
\end{tabular}

$\mathrm{NP}=$ Number of productive tillers; $\mathrm{WGH}=$ Weight of grain hill $^{-1}[\mathrm{~g}]$; $\mathrm{NGH}=$ Number of grain hill ${ }^{-1}$; W1000 $=$ Weight of 1000 grains $[\mathrm{g}]$; $\mathrm{PFG}=$ Percentage of filled grains $[\%] ; \mathrm{GW}=$ Grain weight $\left[\mathrm{t} \mathrm{ha}^{-1}\right]$.

Values in the same column with different lowercase superscript letters differ significantly at $p \leq 0.05$, according to Duncan's Multiple Range Test. ns $=$ non-significant; *, ** significantly different at 0.05 and 0.01 probability levels, respectively. $\mathrm{CV}=$ Coefficient of variation. $1 . \%$ of Recommendation dose viz. $50 \%\left[\mathrm{~N}, \mathrm{P}_{2} \mathrm{O}_{5}\right.$ and $\mathrm{K}_{2} \mathrm{O}$ were $0 \mathrm{~kg} \mathrm{ha}^{-1}, 50 \mathrm{~kg} \mathrm{ha}^{-1}$ and $25 \mathrm{~kg} \mathrm{ha}^{-1}$, respectively] and $100 \%$ [N, $\mathrm{P}_{2} \mathrm{O}_{5}$ and $\mathrm{K}_{2} \mathrm{O}$ were $100 \mathrm{~kg} \mathrm{ha}^{-1}, 100 \mathrm{~kg} \mathrm{ha}^{-1}$ and $50 \mathrm{~kg} \mathrm{ha}^{-1}$, respectively]; 2 . \% of Concentration.

Application of fertilizer with a dose of $50 \% \mathrm{~N}, \mathrm{P}, \mathrm{K}$ was able to produce plant growth characters and equivalent to a dose of $100 \% \mathrm{~N}, \mathrm{P}, \mathrm{K}$, especially in plant height and leaf area as shown in Table 3. This showed that the application of $50 \%$ $\mathrm{N}, \mathrm{P}, \mathrm{K}$ fertilizer was more efficient in producing plant height and leaf area. Upland rice responded application of weed extract by producing the greater shoot and root biomass. Due to a strong relationship between $\mathrm{N}, \mathrm{P}, \mathrm{K}$ fertilizers and weed extract, the application of weed extract was also able to increase the efficiency of using synthetic fertilizers to produce the shoot and root dry weights as shown in Figures 2 and 3.

Natural resources have the potency to explore as an external input in the agricultural system method and no harm to the environment. Appropriate combinations to reduce 
synthetic external application must find to maintain crop production and be environmentally safe. Some studies have been done to explore the capacity of natural material on crop performance. Ozpinar et al. [18] reported that the application of Persica vulgaris (Mill.) leaf extract improved the root and stem growth. The use of natural materials as a biofertilizer could reduce the use of synthetic fertilizers to increase rice production and maintain environmental sustainability [4], such as integrated nutrition management with the application of weeds extract. Moreover, long-term organic farming systems without synthetic fertilizer application improve soil organic carbon and crop production [7].

Secondary metabolites are produced to maintain the cellular functions for physiological processes [19]. There are some chemical content, i.e., alkaloids, phenol, and flavonoid as secondary metabolites in weed extract of Mimosa invisa as shown in Table 2. Secondary metabolite contents in Mimosa invisa have no interfered with rice growth. The secondary metabolites as allelopathy inside weeds, when converted into extracts, have a different role when applying to plants. The application of weed extract during the plant's growth period was an influence on the yield of upland rice. The presence of secondary metabolites improves adaptability to biotic and abiotic stresses in plants, so it enhances plant growth rate [19]. Secondary metabolites such as phenolic and flavonoid have a function as plant protection against herbivory, pathogenic microbes [20]. Various abiotic stresses and flavonoid support plant growth and development, respectively [19].

Therefore, alkaloid, phenol, and flavonoid availability improved plant performance to obtain optimal growth and avoid pests and diseases. Secondary metabolites in Mimosa invisa in the form of extracts were proven to suppress pests and diseases. The level of pest and disease attacks that occurred during the study was very low so that it did not disrupt the growth and development of rice plants.

Application of weed extract at a concentration of $1.67 \%$ $2.5 \%$ was gained a higher $\mathrm{N}$ shoot content as well as $\mathrm{P}$ shoot content as shown in Figures 7 and 8. Also, there had a high impact relation between the application of $\mathrm{N}, \mathrm{P}, \mathrm{K}$ fertilizers, and weed extract on $\mathrm{N}$ shoot content. The availability of synthetic fertilizer of $\mathrm{N}, \mathrm{P}, \mathrm{K}$, along with an increase in the concentration of weed extract, increased $\mathrm{N}$ shoot content. Nutrient uptake in plant tissue will affect plant growth and development.

The accumulation of plant biomass is closely related to the accumulation of nutrients in plants. The accumulation of $\mathrm{N}$ shoot increased with a higher concentration of Mimosa invisa extract and the high application of N-P-K fertilizer. This showed that synthetic fertilizers of $\mathrm{N}$ still play an important role in $\mathrm{N}$ accumulation in plants even though Mimosa invisa extract was given. However, P shoot accumulation showed a different response where the low synthetic fertilizer dosage and the high application of Mimosa invisa extract were able to increase its accumulation in rice plants. The fertilizer doses given will affect the uptake and accumulation of nutrients in plants even though it is supported by other materials to support plant growth and development. Appropriate N, P, K fertilizers application stimulate plant growth and development [21], [22].

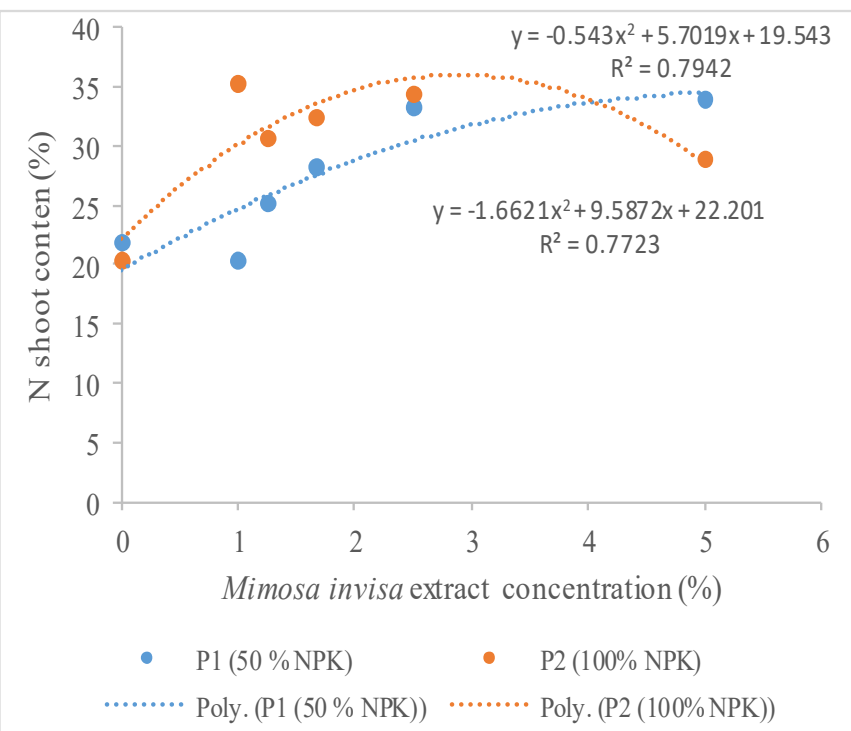

Fig. $9 \mathrm{~N}$ shoot content in different doses of N-P-K along with incresing Mimosa invisa extract concentration.

Figure 9 shows that the application of $50 \%$ and $100 \%$ N-P$\mathrm{K}$ recommended doses with the increasing concentration of weed extract increased the $\mathrm{N}$ shoot content with almost the same $\mathrm{R}^{2}$ viz. 0.79 and 0.77 , respectively. That revealed the application of N-P-K and weed extracts affected improving the $\mathrm{N}$ shoot content. Application of $100 \%$ N-P-K recommended dose with $2.88 \%$ weed extract gained the optimal $\mathrm{N}$ shoot content, but then, the increase in weed extract concentration decreased in the $\mathrm{N}$ shoot accumulation. However, the application of $50 \%$ N-P-K recommended dosage showed an increase in $\mathrm{N}$ shoot accumulation by increasing the concentration of weed extracts. The accumulation of $\mathrm{N}$ shoot increased due to higher application of weed extract at low N-P-K dose. Therefore, it indicated an increase in the efficiency of the application of N-P-K fertilizers. Thus, the accumulation of $\mathrm{N}$ shoot content reflects the plant biomass and directly contributes to establishing the grain yield.

Biomass dry weight because of plant growth reflects nutrient status and nutrients absorbed by plants. This can occur because photosynthate accumulation in plants is supported by more optimal nutrient uptake. Nutrient quality traits through balanced $\mathrm{N}, \mathrm{P}$, and $\mathrm{K}$ fertilizers must maintain soil fertility and produce higher plant biomass and grain yield [23]. Therefore, adequate nutrient uptake will encourage the optimum physiological process by which it will increase crop uptake of nutrients and improve the formation of plant organic substances [24]. Plant biomass in seasonal crops such as rice is closely related to seed formation. High biomass will be a source of nutrients distributed to the seeds during seed filling up to harvesting. It was evident that the grain yield shown in Table 4 was supported by high $\mathrm{P}$ accumulation, as shown in Figure 8.

Rice leaf biomass contains chlorophyll that is an important part of the process of plant growth and development. Photosynthetic activity is related to leaf chlorophyll content, which, if the levels are low, it will reduce plant productivity in accumulating biomass. Thus, abiotic and biotic environmental stress conditions will affect chlorophyll 
contents and photosynthetic activity. Stress conditions will inhibit chlorophyll synthesis in leaves due to decreased photosynthesis rate and finally cause chlorophyll disintegration [25], [26].

One indicator of the level of plant stress is leaf proline content. High proline content indicates that plants are stressed and will interfere with metabolic processes in plants. An increase in stress condition declined chlorophyll content [27] cause inhibits vegetative and generative stages and extensive reduction in its yield [26], [27]. The most important information showed in this study that low N, P, K fertilizers of $50 \%$ recommended dose and weed extract applications did not cause plants to stress by indicated in leaf proline and chlorophyll contents as shown in Table 3. An another study stated that weeds extract of Avena fatua, Melilotus officinalis and Polypogon hissaricus significantly increased chlorophyll content [28]. This revealed that the application of weed extract has a role in the physiological process of plants, especially on leaf chlorophyll content as a source of energy through the photosynthesis process; even this study has not shown a significant impact yet.

Weed extract concentrations of $2.5 \%-5 \%$ produced a high yield of upland rice, as shown in Table 4 . The content of alkaloids in weed extracts can act as a supplier of nitrogen that plant roots can absorb into plant tissues. Alkaloids are nitrogen-containing compounds as growth regulators or as mineral bases to maintain ion balance [29]. The application of weed extract of concentration $2.5 \%-5 \%$ was able to provide a high yield and was a correlation between plant growth and physiological processes. The high number of productive tillers supported optimal crop production in which was related to the amount of grain hill ${ }^{-1}$. Also, high grain weight was supported by the number of filled grains and finally obtained greater the weight of grain as shown in Table 4. Rusdiansyah and Saleh [30] and Liu et al. [31] stated that the optimal metabolic process would gain a high yield with filled rice grains.

Grain weight is an indicator of the ability of the sink organ, in which the seeds attract the assimilation of photosynthesis. The greater sink strength will affect the proportion of assimilates that are partitioned in the shoot [32]. The production of photosynthate correlates to the metabolic rate that is affected by phosphorus. Therefore, the high weight of seeds responded to the high uptake of $\mathrm{P}$ nutrient with high $\mathrm{P}$ shoot content due to weed extracts application by concentrations of $2.5 \%-5 \%$, as shown in Figure 8 .

This study revealed that plant metabolism was not disrupted due to low N, P, K fertilizers and weed extract, including plant growth, nutrients absorption, and yield. The application of weed extract of Mimosa invisa could improve the absorption of plant nutrition and gained a high yield of upland rice even in a low dose of N, P, K fertilizers. Thus, the availability of Mimosa invisa is abundant in every dryland area, especially in tropical areas, and of course, it will not be difficult to utilize as an extraction. Also, research related to their effect on soil microbes due to the application of weed extract with the contents of secondary metabolites is interesting to find out, which was not explored in this study. As mentioned by Jacoby et al. [33] that secondary metabolite enhancement beneficial to microbes.
Organic farming systems are commonly lower in crop yield than the conventional farming system by the input of synthetic fertilizers and pesticides, but variation is substantial [34]. Based on the philosophical point of view, organic agriculture is a concept about nature and not a biological science [35]. In this study, N-P-K and weed extract applications in the concentration of more than $1.67 \%$ gained grain yields of more than $4.0 \mathrm{t} \mathrm{ha}^{-1}$ and $5.0 \mathrm{t} \mathrm{ha}^{-1}$, respectively, as shown in Table 4. This result indicated that the application of Mimosa invisa extract has the potency to develop as complementary natural resources with a low dose of synthetic fertilizer to gain the optimal crop yield. However, this study was carried out in one season, so further studies must be conducted to explore the deep result to find the pertinent scientific information, and it could make it possible to apply in different concentrations or various crops.

In the future, organic farming systems should be developed to fulfill secure and healthy food demand. As mentioned by [36], organic farming systems through proper application can increase yields that support sustainable agriculture in meeting food needs in the future.

\section{CONCLUSION}

Overall, weed extract of Mimosa invisa L. had the opportunity to be developed as a source of nutrition from natural resources in reducing the use of synthetic fertilizers. Through the use of weeds as nutrients for plants will increase its function as a useful biological resource and can be used in agricultural systems. Also, the use of this weed which has large availability in many areas and has not been utilized optimally. Weed extract of Mimosa invisa L. with a concentration of $2.5 \%-5 \%$ could increase the efficiency of $\mathrm{N}$, $\mathrm{P}, \mathrm{K}$ fertilizers dose up to $50 \%$ on plant growth characters, $\mathrm{N}$ and $\mathrm{P}$ shoot contents, and upland rice yield. Therefore, reducing synthetic fertilizers by applying weed extract of Mimosa invisa L. still provides high production and supports an environmentally friendly sustainable farming system.

\section{ACKNOWLEDGMENT}

The authors are grateful to the Research and Community Services Board of Universitas Jenderal Soedirman for funding this research.

\section{REFERENCES}

[1] S. A. A. Taridala et al., "Exploration of the potential of upland rice agribusiness development in South Konawe District, Southeast Sulawesi," IOP Conf. Ser. Earth Environ. Sci., vol. 260, no. 1, pp. 17, 2019.

[2] H. A. Wale and T. Dejenie, "Dryland Ecosystems: Their Features, Constraints, Potentials and Managements," Res. J. Agric. Environ. Manag., vol. 2, no. 10, pp. 277-288, 2013.

[3] S. A. A. Taridala et al., "Understanding the social and economic aspects of upland rice farming," IOP Conf. Ser. Earth Environ. Sci., vol. 122 , no. 1 , pp. $1-7,2018$

[4] B. Kadidaa, G. R. Sadimantara, S. Suaib, L. O. Safuan, and M. Muhidin, "The Effect of Organic Fertilizer in the Increasing of Local Upland Rice Production on Marginal Land in North Buton Indonesia,' Biosci. Biotechnol. Res. Asia, vol. 14, no. 3, pp. 1051-1054, 2017.

[5] W. Jangiam, N. Sangthong, and K. Soontrapiromsook, "Screening of Microorganisms from Homemade Biofertilizers to Promote Plant Growth," Am. J. Sustain. Agric., vol. 12, no. 3, pp. 1-7, 2018.

[6] T. T. Kidane and W. Steven, "An overview use and impact of organic and synthetic farm inputs in developed and developing countries," 
African J. Food Agric. Nutr. Dev., vol. 19, no. 3, pp. 14517-14540, 2019.

[7] D. Dutta et al., "Effect of long-term use of organic, inorganic and integrated management practices on carbon sequestration and soil carbon pools in different cropping systems in Tarai region of Kumayun hills," Indian J. Agric. Sci., vol. 88, no. 4, pp. 523-529, 2018.

[8] J. Pradhan, S. K. Sahoo, S. Lalotra, and R. S. Sarma, "Positive impact of abiotic stress on medicinal and aromatic plants," Int. J. Plant Sci., vol. 12 , no. 2, pp. 309-313, 2017.

[9] C. Jain, S. Khatana, and R. Vijayvergia, "Bioactivity of secondary metabolites of various plants: a review," Int. J. Pharm. Sci. Res., vol. 10, no. 2, pp. 494-504, 2019, doi: 10.13040/IJPSR.09758232.10(2).494-04.

[10] S. U. Putri, J. Jumiatun, and N. Wihartiningsih, "Identification secondary metabolite of weed as organic pesticide on tomato," IOP Conf. Ser. Earth Environ. Sci., vol. 411, no. 1, pp. 1-7, 2020, doi: 10.1088/1755-1315/411/1/012064

[11] A. Carrubba, A. Labruzzo, A. Comparato, S. Muccilli, and A. Spina, "Use of plant water extracts for weed control in durum wheat (Triticum turgidum L. Subsp. durum Desf.)," Agronomy, vol. 10, no. 3, p. 364, 2020

[12] F. Ekhator, O. O. Uyi, C. E. Ikuenobe, and C. O. Okeke, "The Distribution and Problems of the Invasive Alien Plant, Mimosa diplotricha C. Wright ex Sauvalle (Mimosaceae) in Nigeria," Am. J. Plant Sci., vol. 4, no. 4, pp. 866-877, 2013.

[13] R. K. Ranjan, M. S. Kumar, I. Seethalakshmi, and M. R. K. Rao, "Phytochemical analysis of leaves and roots of mimosa pudica collected from Kalingavaram, Tamil Nadu," J. Chem. Pharm. Res., vol. 5, no. 5, pp. 53-55, 2013.

[14] L. S. Bates, "Rapid determination of free proline for water - stress studies," in Plant and Soil, vol. 39, 1973, pp. 205-207.

[15] S. Yoshida, J. H. Forno, Douglas A.Cock, and K. A. Gomez, Laboratory Manual for Physiological Studies of Rice, 3rd ed. Los Banos, Philippines: The International Rice Research Institute, 1976.

[16] M. R. Motsara and R. N. Roy, Guide to laboratory establishment for plant nutrient analysis, 19th ed. Rome, Italy: Fooad and Agriculture Organization of The United Nations, 2008

[17] IRRI, “Cropstat ver 7.2.” Los Banos, Philippines, 2007.

[18] H. Ozpinar, S. Dag, and E. Yigit, "Alleophatic effects of benzoic acid, salicylic acid and leaf extract of Persica vulgaris Mill. (Rosaceae)," South African J. Bot., vol. 108, pp. 102-109, 2017.

[19] T. Isah, "Stress and defense responses in plant secondary metabolites production," Biol. Res., vol. 52, no. 39, pp. 1-25, 2019

[20] M. Zaynab et al., "Role of secondary metabolites in plant defense against pathogens," Microb. Pathog., vol. 124, pp. 198-202, 2018.

[21] A. Redda, K. Hailegebriel, T. Yirgalem, W. Redae, G. Welegerima, and S. Husien, "Effects of $\mathrm{N}$ and P Fertilizer Application Rates on Yield and Economic Performance of Upland Rice in Tselemti District of N.W Tigray, Ethiopia," Rice Res. Open Access, vol. 6, no. 2, pp. 18,2018 .
[22] D. D. Adi, I. Lubis, S. Suwarto, and S. Sugiyanta, "Determination of the Optimum Rates for N, P, and K Fertilizer for Upland Rice Variety 'IPB 9G,"' J. Trop. Crop Sci., vol. 6, no. 3, pp. 164-173, 2019.

[23] J. Ali, Z. A. Jewel, A. Mahender, A. Anandan, J. Hernandez, and Z. $\mathrm{Li}$, "Molecular genetics and breeding for nutrient use efficiency in rice,” Int. J. Mol. Sci., vol. 19, no. 6, pp. 1-27, 2018.

[24] D. Sarkar and L. K. Baishya, "Nutrient Use Efficiency," in Essential Plant Nutrients: Uptake, Use Efficiency, and Management, M. Naeem, Ed. West Bengal, India: Springer International Publishing, 2017, p. 569.

[25] A. Sharma et al., "Photosynthetic response of plants under different abiotic stresses: A review," J. Plant Growth Regul., vol. 38, no. 3, pp. 1-23, 2019.

[26] S. Hanif et al., "Biochemically Triggered Heat and Drought Stress Tolerance in Rice by Proline Application," J. Plant Growth Regul., vol. 39 , no. 1 , pp. 1-8, 2020.

[27] M. Meena et al., "Regulation of L-proline biosynthesis, signal transduction, transport, accumulation and its vital role in plants during variable environmental conditions," Heliyon, vol. 5, no. 12, pp. 1-20, 2019.

[28] S. Siyar, A. Majeed, Z. Muhammad, H. Ali, and N. Inayat, "Allelopathic effect of aqueous extracts of three weed species on the growth and leaf chlorophyll content of bread wheat," Acta Ecol. Sin., vol. 39, no. 1, pp. 1-6, 2019.

[29] L. N. Zhou, X. L. Ge, T. T. Dong, H. Y. Gao, and B. H. Sun, "Antibacterial steroidal alkaloids from Holarrhena antidysenteriaca," Chin. J. Nat. Med., vol. 15, no. 7, pp. 540-545, 2017.

[30] R. Rusdiansyah and M. Saleh, "Response of two local rice cultivars to different doses of nitrogen fertilizer in two paddy fields," Agrivita, vol. 39, no. 2, pp. 137-144, 2017.

[31] H. Liu, J. Zhan, S. Hussain, and L. Nie, "Grain yield and resource use efficiencies of upland and lowland rice cultivars under aerobic cultivation," Agronomy, vol. 9, no. 10, p. 591, 2019.

[32] N. Philipp, H. Weichert, U. Bohra, W. Weschke, A. W. Schulthess, and $\mathrm{H}$. Weber, "Grain number and grain yield distribution along the spike remain stable despite breeding for high yield in winter wheat," PLoS One, vol. 13, no. 10, pp. 1-17, 2018, [Online]. Available: http://dx.doi.org/10.1371/journal.pone.0205452.

[33] R. P. Jacoby, A. Koprivova, and S. Kopriva, "Pinpointing secondary metabolites that shape the composition and function of the plant microbiome," J. Exp. Bot., vol. 71, no. 20, pp. 1-12, 2020.

[34] M. Brückler, T. Resl, and A. Reindl, "Comparison of organic and conventional crop yields in Austria," Bodenkultur, vol. 68, no. 4, pp. 223-236, 2017.

[35] H. Kirchmann, "Why organic farming is not the way forward," Outlook Agric., vol. 48, no. 1, pp. 22-27, 2019.

[36] K. P. Wilbois and J. E. Schmidt, "Reframing the debate surrounding the yield gap between organic and conventional farming," Agronomy, vol. 9 , no. 2 , p. $82,2019$. 